\title{
GENETIC AND ENVIRONMENTAL CONTRIBUTIONS TO INCREASED WHEAT YIELD IN MINAS GERAIS, BRAZIL
}

\author{
Adeliano Cargnin $^{1 *}$; Moacil Alves de Souza ${ }^{2}$; Vanoli Fronza ${ }^{3}$; Cláudia Martellet Fogaça ${ }^{1}$ \\ ${ }^{1}$ Embrapa Cerrados - C.P. 08223 - 73310-970 - Planaltina, DF - Brasil. \\ ${ }^{2} U F V$ - Depto. de Fitotecnia - Av. Peter Henry Rolfs, s/n ${ }^{o}$ - 36571-000 - Viçosa, MG - Brasil. \\ ${ }^{3}$ Embrapa Soja - C.P. 321 - 86001-970 - Londrina, PR - Brasil. \\ *Corresponding author <adeliano@cpac.embrapa.br>
}

\begin{abstract}
Producers need wheat cultivars adapted to the predominant climate conditions of the end of the rainy period. Having this in mind, EPAMIG (Agriculture and Livestock Research Institute of Minas Gerais) has been developing a wheat genetic improvement program since 1976, and the estimates of the genetic improvement established by the breeding programs could be useful to quantify their efficiency. This study focused on the quantification of the genetic progress achieved by these improvement programs of dryland wheat in the Brazilian-savanna between 1976 and 2005. The efficiency of these programs was evaluated based on grain yield data of VCU (Value for Cultivation and Use) trials conducted at ten locations in the Minas Gerais State, Brazil. The mean estimated genetic progress for mean grain yield between 1976 and 2005 was $37 \mathrm{~kg} \mathrm{ha}^{-1}$ year $^{-1}$. The genetic yield gain in the study period indicates that the improvement programs of dryland wheat in the Brazilian-savanna are effective. Besides the marked contribution of genetic gain, the environmental and technological improvements were also relevant for the yield, accounting for $47.4 \%$ of the total progress in the period. The improvement programs of dryland wheat resulted in a genotype renovation rate of $35 \%$ over the years. Key words: Triticum aestivum L., genotype evaluation, breeding program, genetic gain
\end{abstract}

\section{CONTRIBUIÇÕES GENÉTICAS E AMBIENTAIS PARA AUMENTO DO RENDIMENTO DO TRIGO EM MINAS GERAIS, BRASIL}

\begin{abstract}
RESUMO: Devido à necessidade dos produtores por cultivares de trigo adaptados às condições climáticas do final da época das chuvas, desde 1976 a EPAMIG (Empresa de Pesquisa Agropecuária de Minas Gerais) vem desenvolvendo um programa de melhoramento genético. As estimativas dos progressos genéticos alcançados pelos programas de melhoramento são instrumentos hábeis para se quantificar a eficiência dos trabalhos executados. Quantificou-se o progresso genético obtido pelos programas de melhoramento do trigo de sequeiro no cerrado brasileiro no período de 1976 a 2005 utilizando-se resultados de produtividade de grãos obtidos nos ensaios de valor de cultivo e uso. O progresso genético médio anual estimado no período de 1976 a 2005 foi de $37 \mathrm{~kg} \mathrm{ha}^{-1} \mathrm{ano}^{-1} \mathrm{na}$ produtividade média de grãos. O ganho genético, em produtividade, obtido no período estudado, indica que os programas de melhoramento de trigo de sequeiro no cerrado brasileiro são eficientes. Apesar de o ganho genético ter contribuído expressivamente, as melhorias ambientais e tecnológicas foram importantes para o acréscimo na produtividade, representando $47,4 \%$ do progresso total obtido. Os programas de melhoramento de trigo de sequeiro promovem $35 \%$ de renovação de genótipos ao longo dos anos.

Palavras-chave: Triticum aestivum L., avaliação de genótipos, programa de melhoramento, ganho genético
\end{abstract}

\section{INTRODUCTION}

Since the seventies of the last century, wheat has expanded towards the Midwest of Brazil, where it is grown on soils of the Cerrado (Brazilian savanna) area, with quite promising results (Souza \& Ramalho, 2001; Cargnin et al., 2006). Although the planted area of dryland wheat is small, this crop type represents an alternative in succession to early soybean, as an in- come complement to producers, besides increasing land use efficiency and reducing machine idleness, among other advantages. Moreover, as a rising number of soils has become infested by the soybean cyst nematode Heterodera glycines, new production systems are needed to be able to coexist with this new problem that threatens Brazilian soybean cultivation.

Producers need wheat cultivars adapted to the predominant climate conditions of the end of the rainy 
period. Therefore, EPAMIG (Agriculture and Livestock Research Institute of Minas Gerais) has been developing a wheat genetic improvement program since 1976. The estimates of the genetic improvement established by the breeding programs could be useful to quantify their efficiency.

Some methodologies were developed to quantify the genetic improvement obtained with these breeding programs. Ideally, the methods would make use of the information as it becomes available throughout the trials (Atroch \& Nunes, 2000). Therefore, Vencovsky et al. (1986) suggested a method that uses data of cultivar evaluation trials conducted by research institutions. This method was applied in the different studies that estimate the contribution of the genetic improvement for different crops under Brazilian conditions.

Based on this background, this study aimed to quantify the genetic improvement obtained by dryland wheat breeding programs in the Brazilian-savanna between 1976 and 2005, conducted by EPAMIG in Minas Gerais State, Brazil.

\section{MATERIAL AND METHODS}

Grain yield data of dryland wheat in the state of Minas Gerais obtained in trials conducted by partner research institutions under the administration of EPAMIG from 1976 to 2005 were used in this study. In the trials, a group of genotypes (cultivars and/or lines) that did not perform well, was annually discarded and replaced by others. On the other hand, a second genotype group with good performance was annually maintained for evaluation in the following year. One genotype could therefore be found in the evaluations for two or more years, depending on the annual performance.

The trials were conducted in randomized block designs, with three replications. Data of yearly grain yield of the cultivars and/or lines were used. The means were replicated $\mathrm{k}$ times for each genotype, according to the number of trials and the number of replications. The experiments from 1989 and 1999 were lost due to a strong drought.

The trials were conducted at ten sites in the state of Minas Gerais: Capinópolis $\left(18^{\circ} 40^{\prime} \mathrm{S}, 4^{\circ} 34^{\prime}\right.$ $\mathrm{W}, 564 \mathrm{~m}$ altitude), Coromandel $\left(18^{\circ} 28^{\prime} \mathrm{S}, 47^{\circ} 12^{\prime} \mathrm{W}\right.$, $976 \mathrm{~m})$, Iraí de Minas $\left(18^{\circ} 59^{\prime} \mathrm{S}, 4^{\circ} 27^{\prime} \mathrm{W}, 951 \mathrm{~m}\right)$, Presidente Olegário $\left(18^{\circ} 25^{\prime} \mathrm{S}, 46^{\circ} 25^{\prime} \mathrm{W}, 947 \mathrm{~m}\right)$, Paracatu $\left(17^{\circ} 13^{\prime} \mathrm{S}, 46^{\circ} 52^{\prime} \mathrm{W}, 687 \mathrm{~m}\right)$, Patos de Minas $\left(18^{\circ} 34^{\prime} \mathrm{S}, 46^{\circ} 31^{\prime} \mathrm{W}, 832 \mathrm{~m}\right)$, Perdizes $\left(19^{\circ} 21^{\prime} \mathrm{S}\right.$, $\left.47^{\circ} 17^{\prime} \mathrm{W}, 1,000 \mathrm{~m}\right)$, Rio Paranaíba $\left(19^{\circ} 11^{\prime} \mathrm{S}, 46^{\circ} 14^{\prime}\right.$ W, $1,067 \mathrm{~m})$, São Gotardo $\left(19^{\circ} 18^{\prime} \mathrm{S}, 46^{\circ} 02^{\prime} \mathrm{W}, 1,055\right.$ $\mathrm{m})$ and Uberaba $\left(19^{\circ} 44^{\prime} \mathrm{S}, 47^{\circ} 55^{\prime} \mathrm{W}, 801 \mathrm{~m}\right)$.
Sowings were performed during the recommended period, from January 15 to the end of February, until March 10 for the Alto Paranaíba region or until March 25 for São Gotardo and Rio Paranaíba. The experiments were not fungicide treated, except for those of São Gotardo, 2000 onwards. All other cultural practices were performed according to the wheatspecific indications of the "Comissão Norte ou Centro Brasileira de Pesquisa de Trigo" (Wheat research commission of northern and central Brazil) and effective in the trial period. In Rio Paranaíba, the trials were grown under complementary central pivot irrigation during the beginning of the cycle (not more than three irrigations), from 2001 onwards.

The methodology proposed by Vencovsky et al. (1986) was used to calculate the genetic progress. This methodology allows the calculation of the mean progress estimate based on information of genotype sets evaluated in a particular period. It takes into account that new genotypes are produced by improvement programs every year and included in competition trials together with others that are kept by in view of the yield capacity, adaptability and, acceptance by producers. Genotypes which, for some reason, are eventually outmatched were excluded as well.

The difference between the yield mean of the common genotypes of each pair of years was used to estimate the year effect. The annual genetic advance was computed by the difference between the mean yield of a genotype of one year and that of the year immediately before, excluding the year effect. Thus, the genetic improvement of the two consecutive years 1 and 2 was estimated by the difference: $g d_{21}=t d_{21}-$ $a d_{21}$, where: $t d_{21}=\left(\bar{Y}_{2}-\bar{Y}_{1}\right)$, the total difference between the mean of all treatments of year 2 and that of all treatments in year 1 , where $\bar{Y}_{2}$ and $\bar{Y}_{1}$ are the means of all genotypes in the years 2 and 1, respectively; $a d_{21}$ $=\left(\bar{Y}_{(21) 2}-\bar{Y}_{(21) 1}\right)$ is the environmental difference obtained between the group mean of the same group of genotypes evaluated in years 2 and 1, where $\bar{Y}_{(21) 2}$ and $\bar{Y}_{(21) 1}$ are the separate genotype means of those common to both years, obtained in the years 2 and 1, respectively.

This procedure provides estimates of increase in the variable resulting from the improvement of the available genotypes and environmental conditions. With "a" years the genetic and environmental differences between each pair of successive years are "a 1". The sum of all $g d$ and $a d$ values represents grain yield increases from the beginning to the end of the period, due to the genetic and environmental changes throughout the years. To obtain the mean increase per year, the accumulated progress was divided by the number of years in the period. This latter estimate divided by 
the overall experimental mean of the first year (reference mean), multiplied by 100 , express the mean annual genetic gain in percentage (Vencovsky et al., 1986). Following that, the Moresco (2003) t test with $n-2$ degrees of freedom (being $\mathrm{n}$ the total number of years) was used to test the significance of the annual genetic improvement.

The rates of included, excluded, maintained and replaced experimental lines and cultivars from one year to the next were estimated as well, according to the following equations given in percentage values:

$\% I=\frac{100 I}{M+E+I} ; \% E=\frac{100 E}{M+E+I} ; \% M=\frac{100 M}{M+E+I}$ and $\% R=\frac{100 I}{M+I}$. Here: $\mathrm{I}$ is the number of experimental lines and cultivars included in the subsequent year; $E$ the number of experimental lines and cultivars excluded in the previous year; $M$ the number of experimental lines and cultivars maintained from one year to the next; and $\mathrm{R}$ the number of renewed experimental lines and cultivars. All analyses were performed with the GENES software (Cruz, 2001).

\section{RESULTS AND DISCUSSION}

The number of trials per growing season varied from one to four, totaling 53 trials (Table 1). A similar number was used in other studies on the genetic progress of other crops such as rice (Breseghello et al., 1999), although shorter periods were by them considered in relation to the present case. The number of experimental lines and cultivars evaluated in each year varied from 12 to 29 , totalizing 184 evaluated in the period. The mean yield increased in the period between 1976 and 2005 (Table 1).

The experimental lines and cultivars substitution rate quantifies the efficiency of a breeding program by included, excluded, maintained and replaced experimental lines and cultivars from one year to another (Cruz \& Carneiro, 2003). The dryland wheat breeding program achieved a good rate of genotype renovation throughout the entire study period, with a mean rate of $35 \%$, indicating that the breeding programs have been able to release a considerable number of new genotypes each year (Table 2). Soares et al. (1999) and Atroch \& Nunes (2000) found renovation rates in rice of $44 \%$ and $46 \%$ respectively, and reported that these values evidence the high performance of the improvement programs of this crop. Furthermore, the difference between the inclusion and exclusion rates indicates the degree of contribution of the breeding programs in terms of releasing new cultivars.

The environmental variation between years was estimated based on the maintenance rate, i.e., from
Table 1 - Number of trials, number of genotypes evaluated and mean annual yield of dryland wheat from 1976 to 2005 , in Minas Gerais State, Brazil.

\begin{tabular}{|c|c|c|c|}
\hline Year & Number of trials & Number of genotypes & Yield \\
\hline & & & $\mathrm{kg} \mathrm{ha}^{-1}$ \\
\hline 1976 & 2 & 15 & 552 \\
\hline 1977 & 1 & 25 & 911 \\
\hline 1978 & 3 & 18 & 526 \\
\hline 1979 & 2 & 20 & 850 \\
\hline 1980 & 1 & 21 & 1,573 \\
\hline 1981 & 2 & 25 & 1,005 \\
\hline 1982 & 2 & 29 & 1,213 \\
\hline 1983 & 3 & 14 & 1,233 \\
\hline 1984 & 4 & 15 & 1,598 \\
\hline 1985 & 4 & 16 & 1,973 \\
\hline 1986 & 2 & 14 & 1,951 \\
\hline 1987 & 1 & 17 & 1,808 \\
\hline 1988 & 2 & 16 & 1,811 \\
\hline 1989 & - & - & - \\
\hline 1990 & 1 & 15 & 2,900 \\
\hline 1991 & 1 & 15 & 2,555 \\
\hline 1992 & 1 & 15 & 2,624 \\
\hline 1993 & 1 & 14 & 3,181 \\
\hline 1994 & 1 & 14 & 2,133 \\
\hline 1995 & 1 & 12 & 2,621 \\
\hline 1996 & 1 & 12 & 1,521 \\
\hline 1997 & 1 & 16 & 3,600 \\
\hline 1998 & 1 & 17 & 2,270 \\
\hline 1999 & - & - & - \\
\hline 2000 & 1 & 12 & 1,962 \\
\hline 2001 & 2 & 16 & 2,108 \\
\hline 2002 & 3 & 12 & 2,338 \\
\hline 2003 & 3 & 19 & 2,561 \\
\hline 2004 & 3 & 17 & 1,946 \\
\hline 2005 & 3 & 30 & 2,522 \\
\hline Period & 53 & 184 & 1,923 \\
\hline
\end{tabular}

the differences of the common genotypes in the study years (Atroch \& Nunes, 2000). The mean maintenance rate of $52 \%$ allowed a good estimate of the environmental variation. Moreover, this condition is very relevant in the methodology proposed by Vencovsky et al. (1986) for estimating the genetic improvement. It also warrants a greater margin of safety in the progress estimation, by the consequent reduction of the confusion caused by experimental errors and genotype $\times$ year interactions.

This study would be of little value if only a few common genotypes had been used to evaluate the year 
Table 2 - Genotype substitution rates in the trials of dryland wheat in each pair of years, between 1976 and 2005, in the State of Minas Gerais, Brazil.

\begin{tabular}{|c|c|c|c|c|}
\hline $\begin{array}{l}\text { Pair of } \\
\text { Years }\end{array}$ & Inclusion & Exclusion & Maintenance & Replacement \\
\hline & ---- & - & $--\%$ & $-\cdots$ \\
\hline $1977 / 1976$ & 42 & 4 & 54 & 44 \\
\hline $1978 / 1977$ & 17 & 40 & 43 & 28 \\
\hline $1979 / 1978$ & 33 & 26 & 41 & 45 \\
\hline 1980/1979 & 20 & 16 & 64 & 24 \\
\hline 1981/1980 & 19 & 4 & 77 & 20 \\
\hline 1982/1981 & 22 & 9 & 69 & 24 \\
\hline 1983/1982 & 26 & 64 & 10 & 71 \\
\hline $1984 / 1983$ & 36 & 32 & 32 & 53 \\
\hline $1985 / 1984$ & 32 & 27 & 41 & 44 \\
\hline $1986 / 1985$ & 20 & 30 & 50 & 29 \\
\hline 1987/1986 & 22 & 6 & 72 & 24 \\
\hline 1988/1987 & 35 & 38 & 27 & 56 \\
\hline 1990/1988 & 20 & 25 & 55 & 27 \\
\hline 1991/1990 & 25 & 25 & 50 & 33 \\
\hline 1992/1991 & 0 & 0 & 100 & 0 \\
\hline 1993/1992 & 29 & 33 & 38 & 43 \\
\hline 1994/1993 & 0 & 0 & 100 & 0 \\
\hline 1995/1994 & 7 & 20 & 73 & 8 \\
\hline 1996/1995 & 0 & 0 & 100 & 0 \\
\hline 1997/1996 & 52 & 36 & 12 & 81 \\
\hline 1998/1997 & 6 & 0 & 94 & 6 \\
\hline $2000 / 1998$ & 15 & 40 & 45 & 25 \\
\hline $2001 / 2000$ & 43 & 24 & 33 & 56 \\
\hline $2002 / 2001$ & 24 & 43 & 33 & 42 \\
\hline $2003 / 2002$ & 50 & 21 & 29 & 63 \\
\hline $2004 / 2003$ & 24 & 32 & 44 & 35 \\
\hline $2005 / 2004$ & 56 & 23 & 21 & 73 \\
\hline Mean & 25 & 23 & 52 & 35 \\
\hline
\end{tabular}

effects (environment) on account of the way the trials were conducted. The strategy used by the Wheat Research Commission was to include all recommended cultivars as controls, besides the reevaluation of the best tested lines in the following year, which raises maintenance rates. Generally speaking, the genotype maintenance rate of $52 \%$ obtained in this study is considered good. Soares et al. (1999) stated a mean maintenance rate of $56 \%$ in rice, whereas Atroch \& Nunes (2000) verified a rate of only $38 \%$ for the same crop, while Moresco (2003) observed a mean maintenance rate of around $44 \%$ in cotton and found that this allowed a good estimate of the environmental variation between years of evaluation.
During the process of estimation of the genetic and environmental progress, variation were observed in the total, environmental and genetic differences between one year and another, in the period from 1976 through 2005 (Figure 1). The variation in the total differences was strongly linked to the differences of environmental effects that occurred between the years. This probably occurred according to the importance of environmental effects in the determination of the grain yield of the same pair of years, as for instance, the occurrence of greater water stress (less rainfall) in some years. Tthe climate conditions (environment) are the main determinant factors of variations in mean grain yields between years (Carvalho et al., 1980). The year and/or environment are important indeed in the estimates of the genetic progress. In a study carried out during the period 1979 to 1984, Feyerherm et al. (1989) estimated increases in the wheat yield of $8.8 \mathrm{~kg} \mathrm{ha}^{-1}$ year $^{-1}$ in
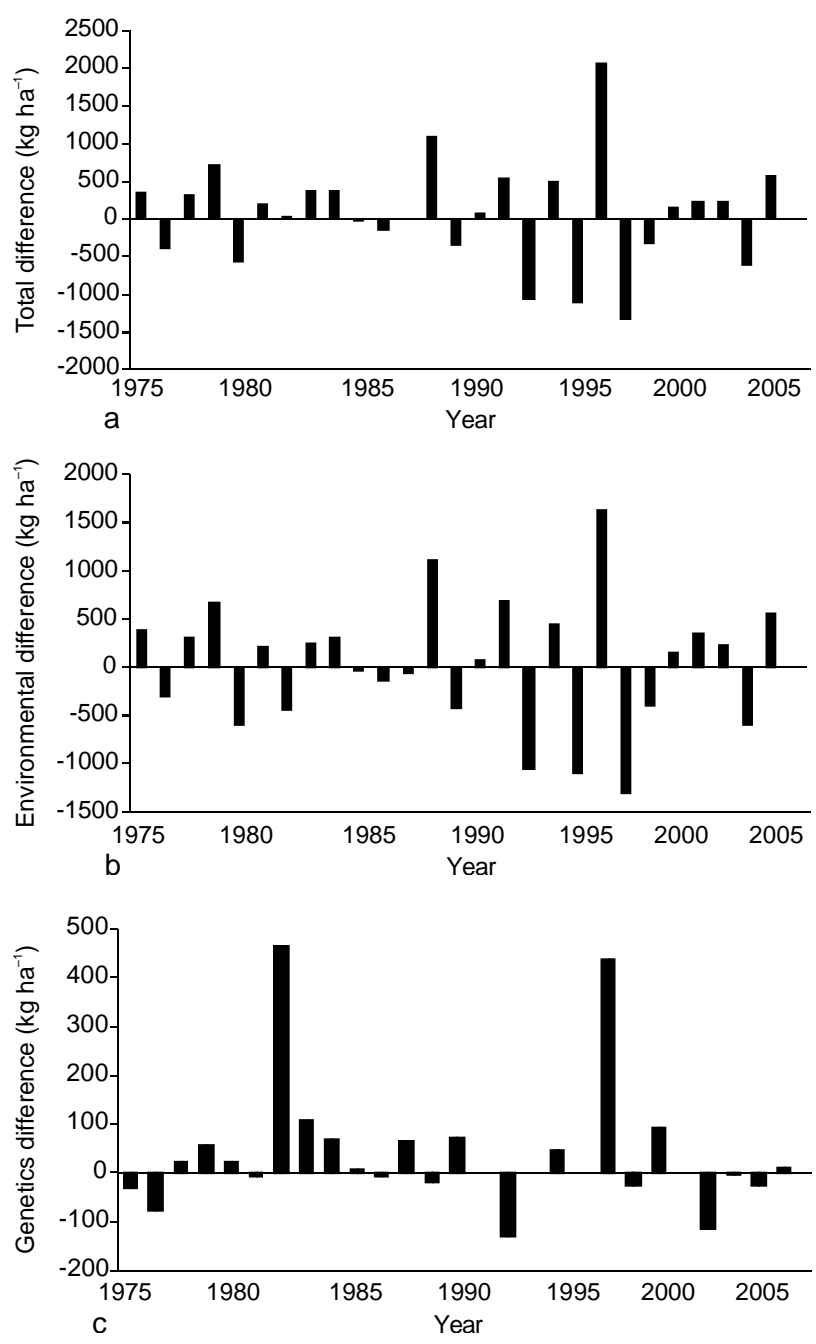

Figure 1 - Total (a), environmental (b) and genetics differences (c) in the trials of dryland wheat in each pair of years, between 1976 and 2005, in the State of Minas Gerais, Brazil. 
Montana, and of $17.6 \mathrm{~kg} \mathrm{ha}^{-1}$ year $^{-1}$ in Dakota, USA, evidencing the environmental effect in the progress estimates.

Likewise, the annual genetic changes were of high magnitude, oscillating from $133 \mathrm{~kg} \mathrm{ha}^{-1}$ to 467 $\mathrm{kg} \mathrm{ha}^{-1}$ (Figure 1). The negative genetic change indicated that for some pairs of years the substitution of discarded genotypes decreased. This had not been expected, but is possible, since the implications of the environment on genotypes are quite relevant in dryland wheat cultivation. However, despite the differences in mean grain yields caused by changes in the genetic effect during the period, it was verified that the positive differences were more marked. This demonstrated the existence of genetic progress over the years, through the release of new cultivars by the wheat breeding programs.

The total improvement (genetic and environmental gain) was $1,971 \mathrm{~kg} \mathrm{ha}^{-1}$ (Table 3). The genetic improvement accumulated throughout the period was $1,035 \mathrm{~kg} \mathrm{ha}^{-1}$, which corresponds to $52.6 \%$ of the total estimated progress, which represents an significant $(p \leq 0.05)$ increase expressed of $37 \mathrm{~kg} \mathrm{ha}^{-1}$ year $^{-1}$. This also means that the mean grain yield increased by about $6.7 \%$ per year, which can be considered a high value, compared to the estimates of other crops (Moresco, 2003).

The genetic progress obtained by the genetic improvement in wheat in Brazilian South region, was more recently reported by Nedel (1994). This author examined the improvement of 15 wheat cultivars released from 1940 to 1992 and observed an increment of $17.3 \mathrm{~kg} \mathrm{ha}^{-1}$ year $^{-1}(0.8 \%)$ in grain yield. In the United States, Cox et al. (1988) reported an increase of $16.2 \mathrm{~kg} \mathrm{ha}^{-1}$ year $^{-1}$. Thus the conducted wheat breeding program could be considered efficient.

Likewise, there was total an environmental and technological increase of $936 \mathrm{~kg} \mathrm{ha}^{-1}$ which represents $47.4 \%$ of the total progress or $33.4 \mathrm{~kg} \mathrm{ha}^{-1}$ year $^{-1}$ (Table $3)$. Actually, a marked yield increase had already been expected, due to the environmental improvement, since the technological management of the crop had been enhanced, as well as the soil fertility of the Cerrado (Brazilian savanna). In some years, the experiments in São Gotardo were conducted under pivot irrigation, following vegetables such as carrot, potato, onion and others. These crops are cultivated at a high technological level, mainly regarding fertilization, which benefited the wheat trials, while supplementary irrigations in the beginning of the cycle further contributed to higher grain yields.

For soybean, the annual genetic gains oscilated between $1.3 \%$ and $1.8 \%$ in Paraná, from 1981 to 1986 (Toledo et al., 1990). For rice, Soares et al. (1999) estimated a progress of $0.84 \%$ to $1.6 \%$ per year in Minas Gerais; in northeastern Brazil, Breseghello et al. (1999) predicted the genetic gain for this crop of $0.77 \%$ per year during the period from 1984 to 1993 . For the genetic progress of herbaceous cotton in northeastern Brazil, Carvalho et al. (1997) obtained a gain of $1.03 \%$ per year for cotton seed yield. In Mato Grosso, Moresco (2003) estimated the genetic progress of cotton seed between $3.7 \%$ and $5.2 \%$ per year, values similar to those estimated here.

The accumulated genetic improvement of the 30 years of dryland wheat in Minas Gerais State presented three distinct phases (Figure 2). The first phase was characterized by negative genetic improvement or of such low magnitude and, consequently, low accumulated increase. In this phase, the breeding program consisted of introducing and testing cultivars of different national and international institutions. These cultivars were not well-adapted to the regional climate. From the beginning of the 80ies until 1993, a breeding program with segregating populations was developed, which initiated the second phase, with high

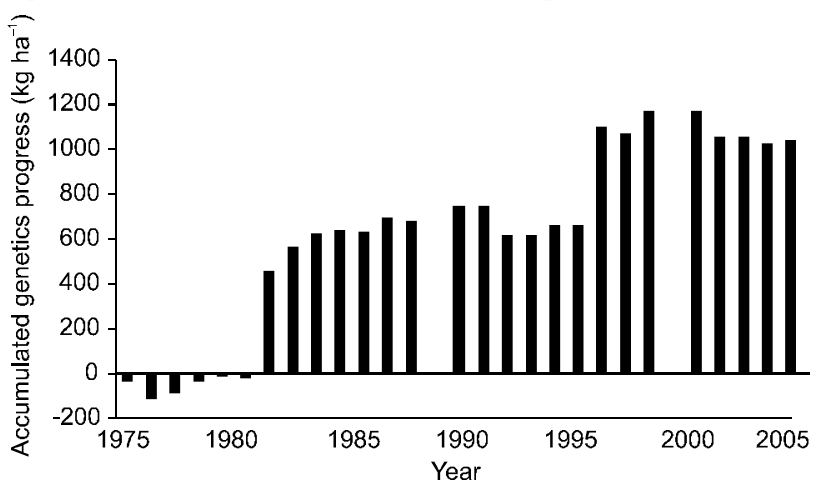

Figure 2 - Genetic improvement built up over 30 years (1976 to 2005) of dryland wheat breeding program in the State of Minas Gerais, Brazil.

Table 3 - Genetic and environmental changes from 1976 to 2005 from the dryland wheat breeding program in the State of Minas Gerais, Brazil.

\begin{tabular}{lccc}
\hline Description of the Gain & Period & Anual & Rate: Genetic/Environment \\
\hline & 1,035 & 37.0 & $\%$ \\
Genetic & 936 & 33.4 & 52.6 \\
Environmental & 1,971 & 70.4 & 47.4 \\
Total & & $\mathrm{kg} \mathrm{ha}^{-1}-4$ & 100 \\
\hline
\end{tabular}


gains, namely in the pair of years $1982 / 1983$, when the genotype renovation rate attained $71 \%$. The third phase, from 1993 on wards, was characterized by activities of breeding with hybridizations and introductions of lines from the CIMMYT (International Maize and Wheat Improvement Center). In this phase, the pair of years 1996/1997 presented the highest gain of the entire study period and a renovation rate of $81 \%$.

The breeding programs developed new cultivars which increased the grain yield in the State of Minas Gerais, representing 52.6\% of the total progress, and the crop management contribuited to $47.4 \%$ to the gain yield increase. In Brazil, Moreira et al. (1982) estimated an increase in wheat yield, owing to genotypes (genetic gain) of $22 \%$ of the total progress and Silvey (1981), in England, of 40\%. Nevertheless, one must bear in mind that no other study estimated the genetic and environmental progress over a similarly long period or by the same methodology.

The efforts undertaken in the search for productive and adapted cultivars have brought forth remarkable results in the dryland wheat breeding programs conducted by state and federal agricultural research institutions developing new dryland wheat genotypes for the State of Minas Gerais.

\section{CONCLUSIONS}

The dryland wheat breeding program conducted in Minas Gerais State was very efficient. The mean annual genetic gain in yield was $37 \mathrm{~kg} \mathrm{ha}^{-1}$ year $^{-1}$, during the period from 1976 to 2005. Environmental improvements were important for the yield increase during the same period accounting for $47.4 \%$ of the total progress. During the entire study period, $35 \%$ of the dryland wheat genotypes were replaced in the improvement programs.

\section{ACKNOWLEDGEMENTS}

To CNPq and Universidade Federal de Viçosa (UFV) for the financial support.

\section{REFERENCES}

ATROCH, A.L.; NUNES, G.H.S. Progresso genético em arroz de várzea úmida no Estado do Amapá. Pesquisa Agropecuária Brasileira. v.35, p.767-771, 2000.

BRESEGHELLO, F.; NAKANO, P.H.R.; MORAIS, O.P. Ganho de produtividade pelo melhoramento genético do arroz irrigado no Nordeste do Brasil. Pesquisa Agropecuária Brasileira, v.34, p.399-407, 1999.
CARGNIN, A.; SOUZA, M.A.; CARNEIRO, P.C.S.; SOFIATTI, V. Interação entre genótipos e ambientes e implicações em ganhos com seleção em trigo. Pesquisa Agropecuária Brasileira. v.41, p.987-993, 2006.

CARVALHO, F.I.F.; FEDERIZZI, L.C.; NODARI, R.C.; SCHEEREN, P.; SERENO, M.J. Trigo, triticale, aveia e cevada da depressão Central do RS. Lavoura Arrozeira, v.33, p.34-39, 1980.

CARVALHO, L.P.; BARBOSA, M.H.P.; COSTA, J.N.; FARIAS, F.J.C.; SANTANA, J.C.F.; ANDRADE, F.P. Progresso genético do algodoeiro herbáceo no Nordeste. Pesquisa Agropecuária Brasileira, v.32, p.283-291, 1997.

COX, T.S.; SHOYER, J.P.; BEN-HUI, L.; SEARS, R.G.; MARTIN, T.J. Genetic improvement in agronomic traits of hard red winter wheat cultivars from 1919 to 1987 . Crop Science, v.28, p.756$760,1988$.

CRUZ, C.D. Programa genes: versão Windows; aplicativo computacional em genética e estatística. Viçosa: UFV, 2001. $648 \mathrm{p}$.

CRUZ, C.D.; CARNEIRO, P.C.S. Modelos biométricos aplicados ao melhoramento genético II. Viçosa: UFV, 2003. 585p.

FEYERHERM, A.M.; KEMP, K.E.; PAULSEN, G.M. Genetic contribution to increased wheat yields in the USA between 1979 and 1984. Agronomy Journal, v.81, p.242-245, 1989.

MOREIRA, J.C.; SOUZA, C.N.A.; MEDEIROS M.C. Avaliação do progresso na criação de cultivares de trigo. In: REUNIÃO NACIONAL DE PESQUISA DE TRIGO, 12., Cascavel, 1982. Anais. Passo Fundo: Embrapa CNPT, 1982. p.109-121.

MORESCO, E. R. Progresso genético no melhoramento do algodoeiro no Estado de Mato Grosso. Piracicaba: USP/ESALQ, 2003. 79p. Tese (Doutorado).

NEDEL, J.L. Progresso genético no rendimento de grãos de cultivares de trigo lançadas para cultivo entre 1940 e 1992. Pesquisa Agropecuária Brasileira. v.29, p.1565-1570, 1994.

SILVEY, V. The contribution of new wheat, barley and oat cultivars to increasing yield in England and Wales. Journal of the Natural Institute of Agriculture Botany, v.15, p.399-412, 1981.

SOARES, A.A.; SANTOS, P.G.; MORAIS, O.P.; SOARES, P.C.; REIS, M.S.; SOUZA, M.A. Progresso genético obtido pelo melhoramento de arroz de sequeiro em 21 anos de pesquisa em Minas Gerais. Pesquisa Agropecuária Brasileira, v.34, p.415-24, 1999.

SOUZA, M.A.; RAMALHO, M.A.P. Controle genético e tolerância ao estresse de calor em populações híbridas e em cultivares de trigo. Pesquisa Agropecuária Brasileira, v.36, p.1245-1253, 2001.

TOLEDO, J.F.F.; ALMEIDA, L.A.; KIIHL, R.A.S.; MENOSSO, O.G. Ganho genético em soja no Estado do Paraná via melhoramento. Pesquisa Agropecuária Brasileira. v.25, p.89-94, 1990.

VENCOVSKY, R.; MORAES, A.R.; GARCIA, J.C.; TEIXEIRA, N.M. Progresso genético em vinte anos de melhoramento do milho no Brasil. In: CONGRESSO DE MILHO E SORGO, 9., Belo Horizonte, 1986. Anais. Sete Lagoas: Embrapa CNPMS, 1986. p. 300-307.

Received June 04, 2007

Accepted December 12, 2008 